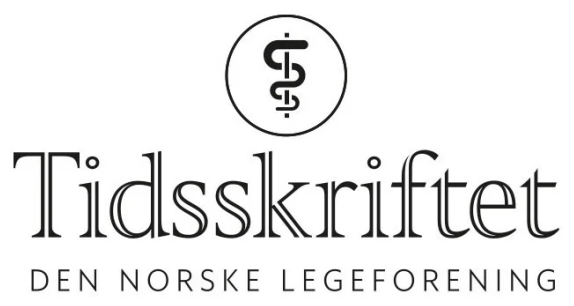

\title{
Er radialisgraft bedre enn venegraft ved bypasskirurgi?
}

FRA ANDRE TIDSSKRIFTER

PETTER MORTEN PETTERSEN

Tidsskriftet

En ny metaanalyse viser bedre langtidsresultater ved bruk av radialisgraft fremfor venegraft ved koronar bypasskirurgi. Bør norske hjertekirurger endre praksis? 


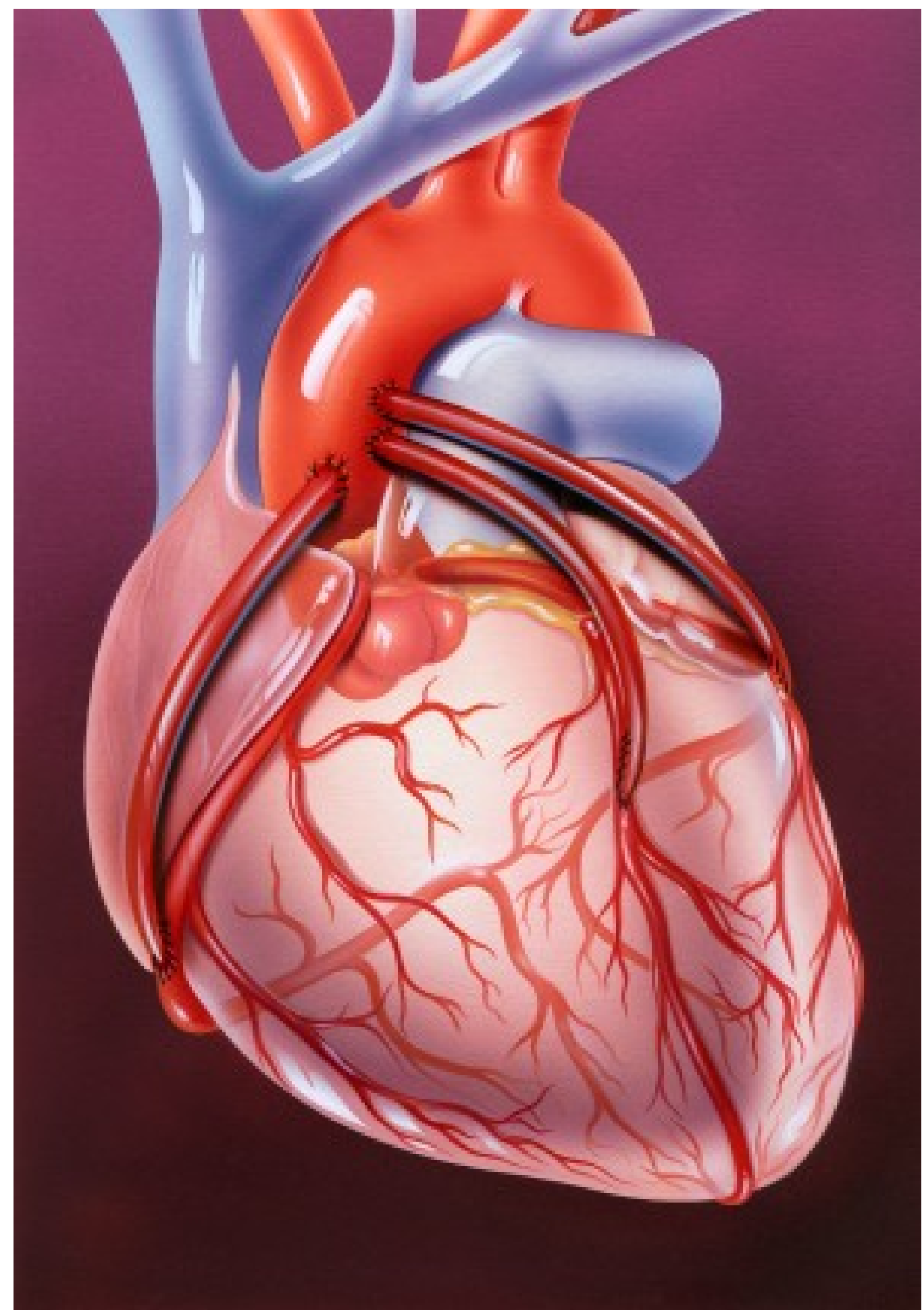

Illustrasjon: Science Photo Library / NTB scanpix

Ved koronarkirugi har bruk av venstre a. mammaria interna (LIMA, left internal mammary artery, også kalt a. thoracica interna) som graft til fremre nedadstigende koronararterie (LAD, left anterior descending artery) vist overlegne langtidsresultater, og dette er anerkjent som gullstandard blant både kirurger og kardiologer. I Norge har det tradisjonelt vært benyttet LIMA til LAD og venegraft til de andre koronararteriene. Arteriell revaskularisering utover bruk av LIMA har blitt mer populært de siste årene.

En ny metaanalyse inkluderte fem randomiserte studier med til sammen 1036 pasienter og undersøkte insidensen av de alvorlige kardiovaskulære komplikasjonene død, hjerteinfarkt og ny prosedyre for revaskularisering ved bruk av a. radialis og v. saphena magna (11). I løpet av en oppfølgingstid på ti år var det signifikant færre komplikasjoner blant pasientene som ble behandlet med radialisgraft, hhv. 41 mot 47 hendelser per 1 ooo pasientår (hasardratio o,73; 95 \% KI o,61-0,88, p < o,o01). 
- Denne studien er grundig og interessant, ikke minst fordi fordelen ved radialisgraft synes å øke over tid, sier Johannes Lagethon Bjørnstad, overlege og førsteamanuensis ved Thoraxkirurgisk avdeling ved Oslo universitetssykehus.

- Det er betydelig entusiasme for arterielle graft i store deler av det internasjonale hjertemiljøet, og de siste årene er det rapportert økt bruk av arterielle graft også til Norsk hjertekirurgiregister, sier Bjørnstad.

- Samtidig har den kliniske erfaringen vært at a. radialis er mer utsatt for spasmer og dermed iskemi enn venegraft, og det hjertekirurgiske miljøet i Troms $\emptyset$ har studert bruk av radialisgraft uten å finne fordeler. Resultater etter bruk av arterielle graft er ikke evaluert $\mathrm{i}$ regi av Norsk hjertekirurgiregister. Data fra Norsk hjertekirurgiregister viser konsistente og svært gode resultater ved koronar bypasskirurgi i Norge, og det norske hjertekirurgiske miljøet bør etter min vurdering ikke endre praksis før resultatene fra den pågående ROMAstudien foreligger, sier Bjørnstad.

\section{LITTERATUR}

1. Gaudino M, Benedetto U, Fremes S et al. Association of radial artery graft vs saphenous vein graft with long-term cardiovascular outcomes among patients undergoing coronary artery bypass grafting. JAMA 2020;324: 179-87. [PubMed][CrossRef]

Publisert: 18. september 2020. Tidsskr Nor Legeforen. DOI: 10.4045/tidsskr.20.0611

(C) Tidsskrift for Den norske legeforening 2023. Lastet ned fra tidsskriftet.no 26. april 2023. 